\title{
FORMULASI SABUN MANDI PADAT BERBASIS MINYAK BIJI KAPUK RANDU (Ceiba pentandra Gaertn) DENGAN PENAMBAHAN JASMINE OIL
}

\author{
Nayyifatus Sa'diyah*, Ninik Indah Hartati, Revy Andar Raesta, Laeli Kurniasari \\ Jurusan Teknik Kimia, Fakultas Teknik, Universitas Wahid Hasyim \\ Jl. Menoreh Tengah X/22, Sampangan, Semarang 50236. \\ *Email : nayyifatus@gmail.com
}

\begin{abstract}
Abstrak
Konsumsi sabun mandi semakin meningkat seiring dengan meningkatnya angka pertumbuhan penduduk. Oleh karena itu perlu dilakukan inovasi terhadap bahan baku pembuatan sabun salah satunya dengan menggunakan minyak biji kapuk sebagai bahan baku formulasi sabun. Biji tanaman kapuk randu mengandung minyak sekitar 24-40\% berat kering. Minyak biji kapuk yang dihasilkan dari biji tanaman kapuk randu dapat dijadikan alternatif untuk dimanfaatkan dalam formulasi sabun. Hal ini dikarenakan kandungan pada minyak biji kapuk menunjukkan aktivitas antibakteri karena pada ekstrak kasarnya mengandung alkaloid, flavonoid, saponin, dan tanin. Tujuan dari penelitian ini adalah (i) untuk mengetahui pengaruh variabel NaOH terhadap sabun yang dihasilkan, (ii) mengetahui hasil analisa sabun yang meliputi organoleptik, kadar air, alkali bebas, dan derajat keasaman $(\mathrm{pH})$ terhadap sabun yang dihasilkan. Tahap dari penelitian ini yaitu formulasi sabun menggunakan 19.1 gram minyak biji kapuk dengan variabel berubah $\mathrm{NaOH} 2,2,5,3,3,5,4$ gram dengan penambahan jasmine oil sebagai aromaterapi. Hasil penelitian menunjukkan hasil formulasi sabun terbaik diperoleh dari variabel $\mathrm{NaOH} 2$ gram dengan berat 4,22 gram, kadar air 0,32\%, alkali bebas 0,01\%, dan nilai derajat keasaman (pH) 10.
\end{abstract}

Kata kunci : formulasi,minyak biji kapuk, $\mathrm{NaOH}$, sabun padat

\section{PENDAHULUAN}

Pertumbuhan penduduk di Indonesia dari tahun ke tahun semakin meningkat, hal itu pula mempengaruhi meningkatnya permintaan suatu barang untuk kebutuhan sehari hari. Salah satu yang cukup penting adalah produk perawatan kulit berupa sabun mandi. Produk sabun mandi telah berkembang menjadi kebutuhan primer hampir di seluruh lapisan masyarakat. Bahkan konsumsi sabun semakin meningkat dari tahun ke tahun. Pada tahun 2004 sebesar 55.832,930 ton yang terus meningkat sampai tahun 2009, yaitu sebesar 101.631,090 ton (BPS, 2009).

Sabun mandi didefinisikan sebagai senyawa Natrium dengan asam lemak yang digunakan sebagai pembersih tubuh, berbentuk padat, berbusa, dengan atau penambahan lain serta tidak menyebabkan iritasi pada kulit. Syarat mutu sabun mandi padat yang ditetapkan oleh SNI yaitu sabun padat memiliki kadar air maksimal $15 \%$, jumlah alkali bebas maksimal $0,1 \%$ dan jumlah asam lemak bebas kurang dari 2,5\% (SNI, 1994).

Permintaan konsumen terhadap sabun mandi yang semakin meningkat setiap tahunnya menyebabkan semakin meningkat pula penggunaan bahan baku minyak untuk produksi sabun. Padahal selama ini kebutuhan minyak untuk produksi sabun dipenuhi dari minyak kelapa dan VCO. Penggunaan minyak nabati murni tersebut untuk produksi sabun memiliki dampak negatif terhadap ketidakseimbangan global karena permintaan pasar dan sumber makanan. Oleh karena itu minyak biji kapuk dapat dijadikan sebagai alternatif bahan baku untuk produksi sabun.

Hasil dari tanaman kapuk yang biasa dimanfaatkan adalah serat, kulit, dan biji. Sedangkan selama ini biji kapuk kurang bernilai ekonomis. Biji kapuk mengandung minyak sekitar $24-40 \%$ berat kering. Biji kapuk yang terkandung pada setiap gelondong buahnya sebesar 26\%, maka setiap $100 \mathrm{~kg}$ gelondong kapuk akan menghasilkan $26 \mathrm{~kg}$ limbah biji kapuk atau 10,04 kg minyak biji kapuk (Dewajani, 2008).

\section{METODOLOGI}

\subsection{Bahan}

Bahan yang akan digunakan dalam penelitian ini adalah minyak biji kapuk, aquadest, $\mathrm{NaOH}$, dan jasmine oil.

\subsection{Alat}

Alat yang akan digunakan dalam penelitian ini antara lain timbangan, beaker glass $100 \mathrm{ml}$, termometer, magnetic stirrer, cetakan sabun.

\subsection{Penetapan Variabel}


Variabel yang digunakan adalah variabel tetap dan variabel berubah. Variabel tetap meliputi berat minyak biji kapuk yaitu 19,1 gram dan jasmine oil 10 tetes. Sedangkan variabel berubah untuk formulasi yaitu $\mathrm{NaOH}$ $2,2,5,3,3,5$, dan 4 gram yang ditunjukkan pada Tabel 1 .

Tabel 1. Komposisi Formulasi Sabun

\begin{tabular}{|c|c|c|c|c|c|c|}
\hline No & Bahan & $\bar{I}$ & II & III & IV & $\bar{V}$ \\
\hline 1 & $\begin{array}{c}\text { Minya } \\
\text { k biji } \\
\text { kapuk } \\
\text { (gram) }\end{array}$ & 19,1 & 19,1 & 19,1 & 19,1 & 19,1 \\
\hline 2 & $\begin{array}{c}\text { Jasmin } \\
\text { e oil } \\
\text { (tetes) }\end{array}$ & 10 & 10 & 10 & 10 & 10 \\
\hline 3 & $\begin{array}{c}\mathrm{NaOH} \\
40 \% \\
\text { (gram) }\end{array}$ & 2 & 2,5 & 3 & 3,5 & 4 \\
\hline
\end{tabular}

\subsection{Prosedur Kerja}

\section{Persiapan alat dan bahan}

Bahan baku yang digunakan adalah minyak biji kapuk yang diperoleh dari proses ekstraksi biji kapuk randu (Ceiba pentandra Gaertn) menggunakan pelarut etanol:n-hexane dengan rasio 5:95 dengan memanfaatkan gelombang mikro pada microwave selama 15 menit dengan daya 50\% dari daya maksimal 399 watt (Hartati, dkk., 2018).

\section{Formulasi}

19,1 gram sampel minyak biji kapuk dipanaskan dalam beaker glass $100 \mathrm{ml}$ sampai mencapai suhu $70^{\circ} \mathrm{C}$ kemudian ditambahkan 10 tetes jasmine oil kemudian aduk hingga homogen. Setelah itu masukkan $\mathrm{NaOH}$ konsentrasi $40 \%$ yang sudah dipanaskan pada suhu $50^{\circ} \mathrm{C}$ dengan variabel $(2,2,5,3,3,5$, dan 4 gram) kedalam minyak biji kapuk dan jasmine oil sedikit demi sedikit. Setelah itu mixing selama 10 menit dengan tetap menjaga kestabilan suhu pada $70-80^{\circ} \mathrm{C}$ menggunakan magnetic stirrer dengan kecepatan $400 \mathrm{rpm}$ sampai membentuk trace, dimana trace adalah kondisi campuran yang telah mengental. Setelah 10 menit, tuangkan campuran tersebut dalam cetakan.

\subsection{Analisa}

Pada penelitian ini akan dilakukan analisa terhadap sabun mandi padat yang meliputi organoleptik, kadar air, jumlah alkali bebas menurut SNI 06-3532-1994, dan tingkat derajat keasaman sabun $(\mathrm{pH})$ menurut SNI No. 064085-1996.

\section{HASIL DAN PEMBAHASAN \\ 3.1.Pengaruh Variabel $\mathrm{NaOH}$ Terhadap Sabun Padat yang Dihasilkan}

Dari pengamatan yang telah dilakukan, Grafik 1. menunjukkan pengaruh variabel $\mathrm{NaOH}$ yang bervariasi terhadap hasil formulasi sabun padat dari minyak biji kapuk.

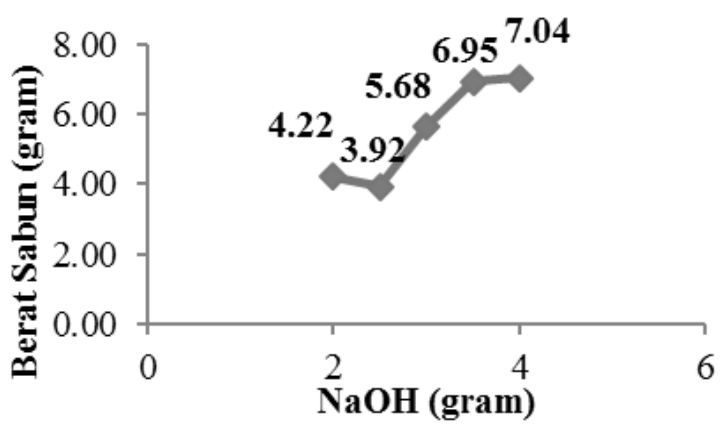

\section{Gambar 1. Pengaruh Variabel $\mathrm{NaOH}$ Terhadap Sabun Padat yang Dihasilkan}

Tren data pada Grafik 1. menunjukkan pengaruh variabel $\mathrm{NaOH}$ terhadap berat sabun padat yang dihasilkan mengalami penurunan pada variabel $\mathrm{NaOH}$ 2,5 gram dengan sabun yang dihasilkan adalah 4,22 gram. Hal ini dikarenakan menguapnya sebagian $\mathrm{NaOH}$ saat dipanaskan karena suhu melewati batas maksimal dalam proses formulasi sabun. Sedangkan pada $\mathrm{NaOH}$ variabel 3, 3,5, dan 4 gram, sabun yang dihasilkan mengalami peningkatan dengan berat sabun yang dihasilkan berturut-turut adalah 5,68 gram, 6,95 gram, dan 7,04 gram. Hal ini dikarenakan semakin banyak reaktan yang digunakan maka reaksi akan bergeser ke kanan yang akan meningkatkan jumlah produk yang dihasilkan sehingga semakin besar variabel $\mathrm{NaOH}$ yang direaksikan maka semakin besar pula berat sabun yang dihasilkan (Sari, dkk., 2010).

\subsection{Analisa Organoleptik}

Analisa organoleptik dilakukan untuk mengamati secara secara visual dari bentuk, warna, dan aroma dari sabun yang dihasilkan. 
Tabel 2. Hasil Analisa Organoleptik Terhadap Sabun yang Dihasilkan

\begin{tabular}{|c|c|}
\hline Pengamatan & Hasil \\
\hline Bentuk & Padat \\
\hline Warna & $\begin{array}{l}\text { Putih } \\
\text { kecokelatan }\end{array}$ \\
\hline Aroma & $\begin{array}{l}\text { Khas } \\
\text { jasmine }\end{array}$ \\
\hline
\end{tabular}

Dari Tabel 2 menunjukkan hasil pengamatan analisa organoleptik terhadap sabun. Dari tabel tersebut dapat dilihat bahwa setelah dicetak dan didiamkan selama satu hari dari semua formula sudah berbentuk padat, hal ini menandakan bahwa reaksi saponifikasi telah terjadi secara keseluruhan sehingga terjadi reaksi antara basa alkali dengan asam lemak secara sempurna. Pada pengamatan warna, seluruh sabun dari semua formula memiliki warna putih kecokelatan. Sedangkan pada pengamatan aroma, semua formula sabun memiliki aroma khas jasmine.

\subsection{Analisa Kadar Air}

Menurut SNI (1994), Prinsip uji kadar air pada formulasi sabun mandi padat adalah pengukuran berat setelah pengeringan pada suhu $105^{\circ} \mathrm{C}$ selama 30 menit. Pengujian kadar air pada sabun mandi padat perlu dilakukan karena kadar air akan mempengaruhi kualitas sabun. Pada Gambar 2. menunjukkan hasil analisa kadar air.

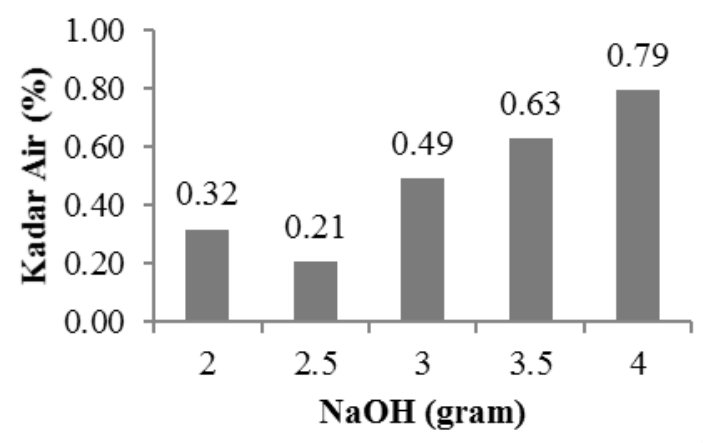

\section{Gambar 2. Analisa Kadar Air}

Dari hasil pengamatan kadar air pada formulasi sabun dengan variabel $\mathrm{NaOH} 2,2,5$, $3,3,5$, dan 4 gram nilai kadar airnya berturutturut adalah $0,32 \%, 0,21 \%, 0,49 \%, 0,63 \%$, dan $0,79 \%$. Secara keseluruhan kadar air dari sabun yang dihasilkan sudah memenuhi syarat SNI 06-3532-1994 karena kadar air dalam sabun padat maksimal adalah $15 \%$. Kelebihan kadar air dari standar SNI akan menyebabkan sabun mudah berbau tengik dan lembek. Dari penelitian yang telah dilakukan pada formulasi sabun bahan baku minyak biji jarak nilai kadar air menurun seiring meningkatnya konsentrasi $\mathrm{NaOH}$ (Sari, dkk., 2010). Sedangkan dalam penelitian ini menggunakan $\mathrm{NaOH}$ dengan konsentrasi yang sama namun dengan variabel yang semakin meningkat sehingga nilai kadar air pada sabun semakin meningkat pula. Banyaknya kadar air dapat mempengaruhi kelarutan sabun dalam air pada saat digunakan. Apabila kandungan air pada sabun terlalu tinggi akan menyebabkan sabun mudah menyusut dan tidak nyaman saat digunakan.

\subsection{Analisa Alkali Bebas}

Uji ini dilakukan untuk mengetahui adanya kelebihan alkali bebas. Menurut SNI (1994), alkali bebas adalah alkali dalam sabun yang tidak terikat sebagai senyawa. Kadar alkali bebas pada sabun maksimum sebesar $0,1 \%$. Alkali dalam sabun mandi tidak boleh melebihi $0,1 \%$ untuk Natrium, karena alkali memiliki sifat yang keras dan dapat mengakibatkan iritasi pada kulit. Bila kadar alkali bebas terlalu tinggi, akan menyebabkan kulit menjadi kering (Hernani dkk., 2010). Analisa alkali bebas bertujuan untuk mengetahui seberapa banyak logam alkali yang tidak tersabunkan, karena nantinya akan berpengaruh pada kualitas sabun yang dihasilkan. Pada Gambar 3. menunjukkan hasil analisa jumlah alkali bebas terhadap sabun yang dihasilkan.

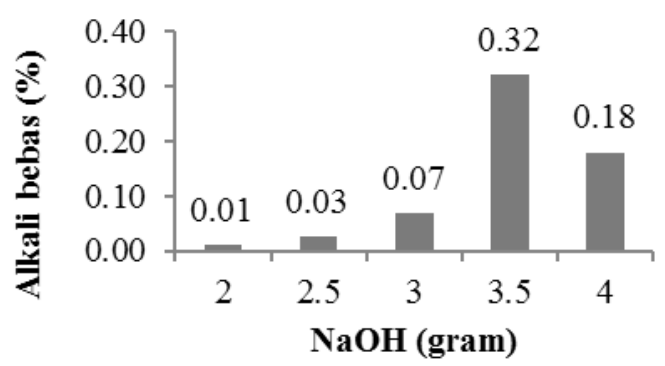

Gambar 3. Analisa Alkali Bebas

Pada tren data tersebut, nilai alkali bebas dari variabel $\mathrm{NaOH} 2,2.5,3,3.5$, dan 4 gram berturut-turut adalah 0,01\%, 0,03\%, 0,07\%, $0,32 \%$, dan $0,18 \%$. Pada formulasi sabun 
variabel $\mathrm{NaOH} 2,2,5$, dan 3 gram telah memenuhi syarat SNI 06-3532-1994 dimana jumlah alkali bebas $0,1 \%$. Namun pada hasil sabun variabel $\mathrm{NaOH}$ 3,5 dan 4 gram memiliki nilai alkali melebihi syarat SNI 06-3532-1994 yaitu diatas $0,1 \%$. Hal ini dikarenakan penambahan alkali yang berlebih pada proses pembuatan sabun. Kelebihan alkali bebas yang tidak sesuai standar dapat menyebabkan iritasi pada kulit (Sari, dkk., 2010).

\subsection{Analisa Derajat Keasaman (pH)}

Nilai $\mathrm{pH}$ merupakan parameter yang sangat penting dalam pembuatan sabun karena nilai $\mathrm{pH}$ menentukan kelayakan sabun untuk digunakan sebagai sabun mandi. Sabun dengan $\mathrm{pH}$ yang terlalu basa dapat meningkatkan daya absorbsi kulit sehingga kulit menjadi iritasi seperti luka, gatal atau mengelupas, dan dapat menyebabkan kulit kering (Sari, dkk., 2010). Pada Gambar 4. menunjukkan hasil analisa nilai $\mathrm{pH}$ terhadap sabun yang dihasilkan.

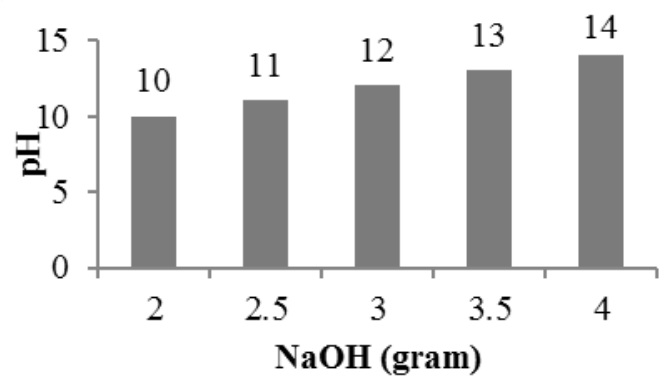

\section{Gambar 4. Analisa Derajat Keasaman (pH)}

Pada data tersebut menunjukkan bahwa semakin meningkatnya nilai variabel $\mathrm{NaOH}$ semakin meningkat pula nilai $\mathrm{pH}$ yang terkandung dalam sabun. Dapat dilihat bahwa nilai $\mathrm{pH}$ pada variabel $\mathrm{NaOH} 2,2,5,3,3,5$, dan 4 gram berturut-turut adalah 10, 11, 12, 13, dan 14. Data tersebut menunjukkan bahwa sabun yang dihasilkan bersifat basa, hal itu dikarenakan $\mathrm{NaOH}$ yang merupakan basa kuat, sehingga mempengaruhi $\mathrm{pH}$ sabun yang menjadi basa Sedangkan syarat nilai $\mathrm{pH}$ yang sesuai dengan SNI No. 06-4085-1996 adalah 811 sehingga pada formulasi sabun dengan variabel $\mathrm{NaOH} 2$ dan 2,5 gram telah memenuhi syarat SNI No. 06-4085-1996.

\section{KESIMPULAN}

Berdasarkan penelitian yang telah dilakukan dengan berbagai pengaruh variabel $\mathrm{NaOH}$ terhadap kualitas sabun meliputi uji organoleptik, uji kadar air, uji alkali bebas, dan uji derajat keasaman $(\mathrm{pH})$ dapat disimpulkan bahwa formulasi sabun terbaik diperoleh dari variabel $\mathrm{NaOH} 2$ gram yang telah memenuhi syarat SNI 06-3532-1994 dengan nilai kadar air $0,32 \%$, alkali bebas $0,01 \%$ dan nilai derajat keasaman $(\mathrm{pH}) 10$ menurut SNI No.06-40851996.

\section{UCAPAN TERIMAKASIH}

Penulis mengucapkan terimakasih kepada Kementerian Riset, Teknologi, dan Pendidikan Tinggi yang telah mendanai seluruh penelitian melalui Program Kreativitas Mahasiswa tahun 2018.

\section{DAFTAR PUSTAKA}

Badan Pusat Statistik, (2009), Data Konsumsi, Produksi, Ekspor, dan Impor Sabun Mandi Padat di Indonesia. Jakarta.

Dewan Standardisasi Nasional, (1994), Standar Mutu Sabun Mandi Padat, SNI 06-35321994, Departemen Perindustrian Nasional, Jakarta.

Dewan Standardisasi Nasional, (1996), Sabun Mandi Cair, SNI 06-4085-1996, Departemen Perindustrian Nasional, Jakarta.

Dewajani, Heny., (2008), Potensi Minyak Biji Randu (Ceiba pentandra) sebagai Alternatif Bahan Baku Biodiesel, Laboratorium Satuan Operasi Skala Kecil Jurusan Teknik Kimia Politeknik Negeri Malang.

Hartati, N.I., Raesta, R.A., Sa'diyah, N., dan Kurniasari, L., (2018), Ekstraksi Minyak Biji Kapuk Randu (Ceiba Pentandra Gaertn) Dengan Ekstraktor Berbantu Gelombang Mikro Sebagai Alternatif Bahan Baku Pembuatan Sabun, Jurusan Teknik Kimia Universitas Wahid Hasyim, Semarang

Hernani, Bunasor K. T., dan Fitriati, (2010), Formula Sabun Transparan Antijamur dengan Bahan Aktif Ekstrak Lengkuas (Alpinia Galanga L.Swartz.), Bul. Littro, 21 (2),192-205.

Sari, Tuti I., Julianti P. K., dan Tri Jayanti, (2010), Pembuatan Sabun Padat Dan Sabun Cair Dari Minyak Jarak. Jurnal Teknik Kimia, No. 1, Vol. 17, Januari 2010. Jurusan Teknik Kimia Fakultas Teknik Universitas Sriwijaya. 